\title{
Systematic Effects of Transnational Partnerships on Local Governance
}

In many decentralized democracies like Mexico, migrant social actors step in to supply public goods when the state lacks sufficient resources or the political will to do so on its own. Migrants' cross-border investment often improves citizens' access to essential goods such as drinking water, paved roads, and bridges, but the process of coordinating service provision also produces significant political consequences in the near and long term. I argue in chapter 1 that when transnational partnerships include residents and local government is engaged, it creates a synergetic partnership. Synergetic partnerships produce new participatory spaces in which residents, migrants, and elected representatives interact, deliberate, and negotiate policy decisions about public goods provision. In this new participatory sphere, state and society become entwined, improving government responsiveness and citizens' interest and engagement in civic and political activities. When the two main factors combine differently, corporatist, substitutive, and fragmented partnerships are more likely to emerge and have different consequences.

In the previous three chapters, I trace the political and social processes that organize partnership differently and link types to political effects. The political consequences include worsening of state-society relations, political disenchantment, corruption, and offloading of responsibility for public goods onto migrant clubs. I also show how partnership types change when social interactions between migrants, residents, and political officials change over time, especially during periods of political party transition in local office. But how well does the theory hold up at meso and macro levels of empirical scrutiny? Are transnational partnerships organized into the types hypothesized in a representative set of cases? Are different types of partnerships associated with changes in political and civic participation 
and government responsiveness? More generally, how systematic are the political effects of different transnational partnerships across places that have them and compared to all Mexican municipalities?

In this chapter, I examine these questions at two levels of aggregation using multiple data sources and statistical analyses. First, using original survey data of a representative sample of migrant-state partnerships, I examine how partnerships are organized. I use principal component and cluster analysis to observe whether partnership types are associated with different political effects in origin communities. In this part of the analysis, I focus on short-term effects given the cross-sectional nature of the survey data. This data represents only a snapshot in time for each partnership. The before-and-after effects focus on the most recent projects and immediate political outcomes. I find that in synergetic and corporatist partnerships, government spending on public works increases, but the duration of the spending increases depends on the level of community inclusion. In substitutive partnerships, the share of government spending on public goods decreases and local citizens become disenchanted with local politics as they become less likely to participate in local elections the longer that such partnerships continue. Fragmented partnerships are more likely to be associated with partnership failure and a worsening of public opinions of government performance.

Next, using panel and longitudinal data from the Mexican Family Life Survey (MxFLS), I examine whether transnational partnerships, regardless of organizational type, change the incidence and frequency of civic and political engagement at the local level. I operationalize civic engagement as local citizen participation in civic associations of varying sorts (social, political, religious) and political engagement as participation in municipal elections. The panel data does not permit the evaluation of how organizational types affect civic and political engagement in the universe of municipal cases of 3x1 participation due to a lack of information on community inclusion and government engagement. To address this data limitation, I move beyond a cross-section of partnerships surveyed at one point in time and investigate how cumulative participation in the program and the frequency of public goods projects affects local governance using panel data. With the addition of a longer observation window from 1990 to 2013 and data on civic engagement from 2000-13 provided by the MxFLS, I can more clearly address how preexisting histories of political and civic participation affect transnational partnerships and, in turn, how those partnerships affect political and civic participation and government responsiveness at the municipal level.

The addition of the MxFLS longitudinal data provides a fruitful opportunity to examine changes in the incidence, type, and frequency of community civic engagement while holding all other factors constant. I find that in places in which partnerships approximate synergy and substitution, the habitual engagement of municipalities in transnational partnerships are associated with more 
citizens participating in municipal elections and civic associations. Overall, in synergetic and substitutive partnerships civic and political participation increases. Additionally, findings reveal that municipalities that participate in the 3x1 Program are more likely to consistently devote more budgetary resources to programmatic spending. The increase in government social spending in response to transnational partnerships signals improvements in government responsiveness in the realm of public goods provision. Taken together, results suggest that more frequent and consistent coproduction activities that bring residents, migrants, and political officials into more routine contact increase civic and political engagement and government responsiveness in local democratic governance. This finding lends further support to the social learning hypothesis I advance in chapter 1.

\section{SURVEYING MEXICAN TRANSNATIONAL \\ PARTNERSHIPS}

Most research on Mexican migrant hometown associations in the United States is based on qualitative interviews with select clubs and ethnography in communities of origin. ${ }^{1}$ In the Mexican context, case-based research has primarily examined HTAs from the traditional sending states of Michoacán, Zacatecas, Jalisco, and Puebla and to a lesser extent the southern indigenous states of Oaxaca and Chiapas. ${ }^{2}$ There are two surveys that examine a larger cross-section of migrant HTAs. ${ }^{3}$ While these surveys enrich our understanding of migrant clubs even more, they lack representativeness because they are isolated to geographic areas of the U.S. and are limited because they do not ask about the structure of transnational partnerships with sending-state governments. Given the lack of systematic data, I developed a national original survey instrument and disseminated it to all registered leaders of Mexican HTAs in the U.S. in the fall of 2008.

The survey questionnaire includes a combination of multiple-choice, open answer, and rank order questions written in Spanish and asks about club formation, goals, and structure, leadership and membership characteristics, transnational partnerships, and 3x1 Program participation, among other themes. The questionnaire was informed by 30 interviews with migrant club leadership in Los Angeles, San Diego, Chicago, Indiana, and North Carolina. Of the 800 associations that self-identified as hometown clubs and registered their clubs with the Mexican government in 2008, 500 listed up-to-date contact information and were sent a paper survey through the U.S. Postal Service. With support from the University of Chicago Survey Lab, surveys were collected and coded through July 2009 with a 50 percent response rate $(n=250) .4$ I describe additional details about the transnational survey instrument and sampling strategy in Data Appendix B.

Since migrant clubs are located in the U.S. but provide public goods in their hometowns in Mexico, I also collected data that characterizes migrant sending and destination places. Taken together, this data creates a transnational statistical 
profile for each club respondent in the survey sample. To my knowledge, this is the first survey to incorporate destination and origin place characteristics in a transnational research design. For each migrant HTA respondent, I compiled sociodemographic and political data for each side of the transnational dyad between destination city and state and origin municipality and state. Data was collected from the American Communities Survey (ACS), Mexican Census (CONAPO), National Institute of Statistic and Geography (INEGI), and Center of Research for Development (CIDAC). This step allows me to assess whether features of the origin and destination also affect partnership dynamics.

I use a three-pronged approach to examine how well survey respondents' transnational partnerships with the Mexican sending state reflect different organization types-synergetic, corporatist, substitutive, and fragmented partnerships. In the first stage, I use transnational survey data to construct a composite index of community inclusion and government engagement, the two multidimensional factors-I hypothesize-that organize coproduction partnerships and whose combination determines political outcomes. This data provides a window into factors that may affect coproduction partnerships at home and abroad as well as characteristics of the HTA. I use principal component analysis (PCA) to reduce highly correlated variables reflective of the multiple dimensions of community inclusion and government engagement. I also develop an indicator for migrant club capacity and examine whether club structure, membership size, and leadership characteristics, for example, are associated with levels of community inclusion and government engagement.

In the second stage, I use the indicators for inclusion, engagement, and club capacity, among other sociodemographic and political characteristics, in a cluster analysis and observe how configurations of all these multiple attributes group together to form groups or clusters of migrant partnerships. In the final stage of the survey analysis, I conduct multivariate statistical analyses to understand how partnership types affect civic and political participation and government responsiveness in the short term. Data Appendix C presents more detailed information on PCA and cluster analysis and Data Appendix D provides more information on the panel analysis.

\section{COMMUNITY INCLUSION AND GOVERNMENT ENGAGEMENT}

The survey asks questions about how migrant clubs integrate local citizens into the coproduction process with the Mexican government. The questions asked migrant clubs how often local citizens in the hometown: (1) volunteered labor; (2) helped select projects; (3) donated resources (monetary or in-kind); (4) monitored projects during and after implementation; (5) discussed project-related activities with municipal officials (i.e., hiring laborers and contractors, timelines, 
technical plans); (6) participated in local committees or mirror clubs (clubes espejo); (7) were involved in the creation of the HTA; and the extent to which (8) the HTA perceived problems working with local citizens and citizen groups; and (9) whether other social, religious, business, and civic associations were involved in the provision of public goods with the HTA. Together, these questions comprise the index for community inclusion created using PCA.

With a combination of survey questions and 3x1 Program data I also construct an index for government engagement. Since sometimes more than one HTA participates in coproduction in a given year, each survey respondent's club name was matched against the 3x1 Program dataset and only the corresponding club information was extracted. Survey questions used to approximate government engagement included questions about municipal government involvement in and frequency of (1) selecting projects; (2) creating the migrant club; (3) providing matching funds and project materials in a timely manner; (4) problems working with the municipal government; (5) matching 25 percent or more of total project costs; and (6) failure to successfully complete coproduction projects. ${ }^{5}$ The survey also asked whether the HTA respondent was able to (7) access officials; (8) participate in decision-making; and (9) influence negotiations with municipal officials.

A few factors are consistently associated with more community involvement in transnational partnerships. First, the mayor's political party affiliation is an important factor. Both the PRI and PAN are more likely to be the municipal party in power in places characterized by high levels of community involvement in transnational public goods projects. Second, community inclusion increases as more projects are designated for localities outside the county seat. This suggests that inclusion is more likely in places with less population density and therefore a smaller social base to mobilize collective action. ${ }^{6}$ Third, places in which religious organizations have been actively involved in providing social welfare are more likely to have higher levels of community involvement. The role of churches both in providing social welfare to the community and in the formation of HTAs has been documented in other studies of migrant HTAs and is further supported by the survey findings. ${ }^{7}$ An active church association and affiliate groups are important preexisting social factors associated with community inclusion. Finally, a higher level of migrant club capacity is positively associated with community inclusion. Clubs with a larger membership base, resources, regular meetings and formal organizational structure, membership in a state-level federation of clubs, and leadership skills are likely to be more inclusive of local residents in transnational partnerships. I discuss migrant club capacity in more depth in the next section.

There are a few important attributes of municipalities that have higher levels of government engagement in coproduction partnerships. Consistent with hypotheses presented in chapter 1, municipalities that have fewer fiscal constraints and therefore more budgetary capacity to invest public resources in coproduction are 
more likely to have higher levels on the government engagement index. I also posit that political officials facing more competition from opposition parties in local elections are likely to engage in transnational partnerships; however, neither the closeness of elections nor party fragmentation is associated with government engagement. Rather, years since the PRI was in power is highly correlated with government engagement. Municipal officeholders in places that have only recently transitioned to democracy-meaning an opposition party (PAN, PRD, Green, Worker, or alliance party, for example) has only recently won a municipal election-are likely to be more engaged in partnerships. This suggests that municipalities in which an opposition party has a shorter institutional memory and experience governing in local office are more likely to engage in partnerships. One interpretation of this finding is that transnational partnerships with migrants help to expand the incumbent party's electoral base of support in places in which the PRI has a long-standing foothold in the municipality. Municipalities with higher levels of government engagement are also those with higher levels of international migration, lower levels of poverty, larger populations, more citizen turnout in local elections, and migrant clubs that have high levels of club capacity. Places in which the local government is more highly engaged are no more likely to be associated with a particular political party nor are they associated with any particular characteristics of the U.S. destination.

\section{MIGRANT HOMETOWN ASSOCIATION CAPACITY TO COPRODUCE PUBLIC GOODS}

During interviews with migrant club leaders that informed the survey questionnaire, several leaders remarked that being in a U.S. city where there are many immigrants, other hometown clubs, and state-level federations of migrant clubs created a network of people to converse with, exchange information, and compare experiences about cross-border partnerships and club activities. In follow-up discussions with migrant club leaders who participated in the survey, and interviews with $3 \times 1$ officials in the U.S. and Mexico, several people explained to me that migrants learned tips on how to organize their clubs from training programs administered by the Mexican consulate and in discussions with other migrant club leaders in nearby municipalities to their hometowns in Mexico. For example, club leaders learned how to structure their club, employ methods for making decisions, develop a mission statement and bylaws, collect dues, and fundraise. Information shared between migrants and Mexican state officials in the U.S. and Mexico proved to be an important factor in how clubs set up and ran their associations and coordinated projects in their respective hometowns.

Given the number of clubs that described the importance of club capacity to their partnerships and evidence in the previous analysis that indicators of club capacity highly correlate with both community inclusion and government 
engagement, I also construct on indicator of club capacity using PCA. Several survey questions ask HTAs about club leadership characteristics, organizational structure and decision-making, membership characteristics, and club activities.

I have found a few factors that are associated with club capacity. First, not surprisingly, U.S. cities with a larger Mexican foreign-born population are more likely to have clubs with higher levels of club capacity. Second, clubs that have previous experience providing public goods projects in the hometown, independent of the Mexican sending state and the 3x1 Program, are associated with higher levels of club capacity. Third, clubs that have participated in the 3x1 Program for several years (prior to the year they took the survey) have higher club capacity scores. Finally, survey respondents that report mimicking some aspects of other HTAs' organizational structure and decision-making also have higher capacity scores. Taken together, this evidence suggest more support for the social learning hypothesis, or organizational isomorphism, at the migrant club level. Organizational isomorphism means that migrant clubs may become similarly structured to other clubs resulting from imitation or development under similar conditions or constraints. Clubs that have the opportunity to learn from each other and adopt best practices are able to improve their capacity to provide public goods and collaborate with state and local partners more effectively. Migrant club capacity is an important determinate of higher levels of community inclusion and government engagement and must be accounted for in the multivariate analysis accordingly. Place-based characteristics such as the density of the Mexican immigrant population in the destination city and concentration of other hometown clubs are important indicators of clubs with higher capacity.

Many club leaders also described how they struggled to retain members' interest in club activities, which required extensive energy and time. The case of Ahuacatl illustrates this sentiment. Migrant leaders described having to frequently plead (some used the word "harass") paisanos to donate resources and take part in the planning and execution of transnational projects. In fact, in several followup phone calls, migrant club leaders asked me if I could share information about how other clubs who took the survey ran their associations so that they could learn how to retain membership involvement and better navigate the difficult process of coordinating public goods projects across national borders. ${ }^{8}$ Many club leaders told me they were frustrated trying to rally the support of paisanos in the U.S. or were becoming aggravated working with political officials in Mexico. Many leaders also shared that they felt isolated in more rural U.S. destinations. Leaders lamented how they wished they were in closer proximity to metropolitan cities like Los Angeles, Chicago, Atlanta, Dallas, Houston, and San Jose so that they could be closer to other migrant clubs and participate in state-level HTA federations. That being said, for some clubs, a high level of club capacity was achievable in new destination areas and with a smaller core group of families or club leadership in lieu of a large paisano membership organization. A dedicated membership 
base was more feasible, some leaders reported, when they also had strong support from local residents and political officials back in the hometown. Developing and maintaining a strong network of paisano support in the U.S., which was key to determining high levels of club capacity, was partially dependent on preexisting community inclusion and government engagement suggesting a feedback effect or an endogenous relationship.

The results of the cluster analysis and interview data confirmed feedback effects inherent in transnational partnerships like those described above. Migrant clubs with high club capacity were not necessarily those that were more socially embedded in the community and therefore more likely to include residents in the coproduction process. Nor were they necessarily the clubs that motivated political actors to engage in partnerships and complete their obligations. This is consistent with evidence in the case of Santa Catarina. But clubs that drew on the social resources in the social base of the hometown were able to overcome club capacity issues and learned new ways to encourage members to become more interested in club activities. Moreover, clubs learned about the benefits of community inclusion when they exchanged information with other clubs. Clubs that did not recruit local residents into the coproduction process implemented new outreach activities in the hometown when other club leaders described to them the value of local resident participation. Information sharing across migrant clubs both influenced the level of HTA capacity and had feedback effects on community inclusion and engagement.

Finally, analysis of the structure of migrant clubs revealed that despite many migrants' best intentions and recruitment efforts, sometimes local residents did not want to engage in coproduction with migrant and state actors. While the multivariate analysis did not reveal that poverty or political histories were systematically associated with community inclusion, it is quite likely that long histories of distrust in political officials, especially in authoritarian enclaves, and places in which residents have fewer resources, skills, and time to participate in projects contribute to low levels of community inclusion despite a migrant club that has a higher capacity for public goods provision.

The case of Club Jilotepec from the state of Mexico and located in San Jose, California, supports this interpretation of the data. The club formed in 2008 with only a few members and grew to 30 active members and over 100 extended members over the span of a calendar year. They fundraised through picnics and raffles and had the support of a large migrant network in San Jose. The club held regular meetings and most of the leadership had lawful permanent residency status (green card holders), which allowed them to visit the hometown at least once a year, sometimes more. Despite strong bonding ties to many migrant families in their hometown of 895 residents and consistent efforts to recruit residents into the partnership, club leaders explained that locals remained uninterested in their club activities. Migrants suggested that local residents were too politically apathetic to participate in any activities that involve the local PRI government, which 
was perceived to be too untrustworthy to partner with on coproduction projects. For Club Jilotepec, this was frustrating because they recognized that a lack of community involvement - that is, a lack of more "eyes and ears" on the ground-made them vulnerable to unscrupulous political officials. Since we spoke in 2009, community residents were content to be the beneficiaries of completed projects but remained uninvolved in the transnational partnership despite migrant club members' active efforts to recruit them into coproduction activities.

Community inclusion, government engagement, and club capacity are important factors involved in the organization of transnational partnerships in migrant hometown communities. But do the key factors analyzed in the case studies and survey combine to create stable transnational partnership types consistent with the framework presented in chapter 1 ?

\section{IDENTIFYING TYPES OF TRANSNATIONAL \\ PARTNERSHIP USING SURVEY DATA}

I use cluster analysis to identify different clusters or "types" of transnational partnership using the original survey data. With this method, I differentiate and compare partnership types and examine the set of characteristics that are more associated with each type or cluster. Overall, the cluster analysis confirms that partnerships vary according to combinations of different levels of community inclusion and government engagement while holding migrant club capacity constant. Including sociodemographic and political characteristics of origin and destination, I consistently observe the formation of four stable partnership clusters: synergy (high community inclusion / high government engagement), corporatist (low community inclusion / high government engagement), substitutive (high community inclusion / low government engagement), and fragmented (low community inclusion / low government engagement). ${ }^{9}$

Additionally, since we learn in the previous analysis that migrant club capacity is an important attribute of both government engagement and community inclusion, I also relax the assumption that club capacity is constant and include the club capacity index as an additional variable in the cluster analysis. The objective here is to observe whether club capacity has an independent effect on how coproduction partnerships group together. When I include the index for club capacity (resources, leadership characteristics, organizational structure, membership size), an additional partnership type emerges along with synergetic, corporatist, substitutive, and fragmented partnerships. In this additional cluster, clubs with more capacity but low levels of community inclusion and government engagement form an additional, stable partnership type. I refer to this type of partnership as apex partnerships since migrant clubs complete the lion's share of project coordination with minimal support from residents and political officials in their hometowns. 
Cluster analysis, while underutilized in sociological studies of international migration, gives me an opportunity to externally validate my claim that migrantstate partnerships organizationally vary beyond the small number of cases I examine in the field. This additional methodological step provides more compelling evidence that transnational coproduction partnership types are more likely to be associated with different political consequences. Moreover, informed by the interview data with migrant club leaders, I also had reason to suspect that levels of club capacity would affect partnership dynamics. The combination of inductive and deductive reasoning pushed me to analyze the role of capacity in the organization of partnerships. As a result, an additional hybrid partnership form emerged from the empirical data whose political consequences could also be analyzed along with the four main coproduction types that I originally theorized.

\section{POLITICAL PARTICIPATION AND \\ GOVERNMENT SPENDING BEFORE AND AFTER \\ TRANSNATIONAL PARTNERSHIPS}

The cluster analysis consistently reveals four partnership types: 55 cases of synergetic partnership, 69 cases of fragmented partnership, 51 cases of substitutive partnership, and 38 cases of corporatist partnership. Of the 250 club respondents, 37 were in places with usos y costumbres for which no political outcomes were available for analysis. For the 213 partnerships cases for which complete data is available, I use multivariate regression and assess the change in how many local citizens of voting age took part in municipal elections and the change in government spending on public works before and after the transnational partnerships, holding all other factors constant. Voter turnout and government social spending represent two key indicators of local democratic participation and government responsiveness. ${ }^{10} \mathrm{I}$ also assess how partnerships affect civic and political participation using survey questions and data from the MxFLS. Data Appendix D contains more detailed information about model specifications, explanatory variables, and controls.

\section{SYNERGETIC PARTNERSHIPS}

In one group of partnerships, clubs had higher levels of community inclusion and government engagement consistent with the synergetic type of coproduction. In these partnerships, residents in the hometown were more frequently involved in volunteering labor, selecting projects, donating resources or labor, monitoring project implementation and upkeep, and discussing project activities with municipal officials. Residents were also regularly involved in issues such as hiring laborers and contractors for projects, timelines for completion, technical plans, and local committees or mirror clubs. The local government was also more likely to engage in selecting projects, providing the requisite matching funds in full and in 
a timely manner, and completing projects according to the timeline when migrant clubs had more frequent access to and negotiating leverage with political officials. Results also reveal that synergetic partnerships were those in which the municipal government had more local-state capacity and were also more likely to be characterized by medium levels of international migration and poverty. Synergetic partnerships were no more likely to be associated with a particular political party of the incumbent.

In the 55 cases that approximate synergetic partnerships, there was no systematic change in the number of citizens participating in local elections in the period immediately following the most recent coproduction project. Places with synergy were no more likely to experience more citizens turning out to vote in local elections than in municipalities with other kinds of partnerships in the electoral period immediately following the most recent coproduction project. I offer four interpretations of the nonfinding for voter turnout.

First, the citizens and citizen groups that were active partners in transnational public goods provision already may have been those individuals who turned out to vote in local elections, which explained why there was no systematic changes in voter turnout in the election immediately after the most recent coproduction project. Second, it could be that the number of citizens involved in partnership who voted were simply too small a number to be observed in the aggregate. Third, and by contrast, citizens included in partnerships may have been those who did not regularly participate in politics and required more time and information to develop political interest and personal efficacy before going to the polls. Finally, citizens are often motivated to participate in elections when they are unhappy and have recourse to punish the incumbent for poor performance in office. Citizens who became active, equal partners in the provision of public goods and helped set the spending agenda, selected projects, and interacted with government partners may have chosen to focus their political activity on nonelectoral forms of political engagement because they perceived local officeholders to have performed well in office.

While there is no observable relationship between the 55 cases of synergy and short-term voter turnout, there is an indication that local citizens became more involved in nonelectoral forms of participation and there were also indications of short-term, positive effects on government responsiveness. Survey results also showed that local citizens became more involved in community affairs beyond public goods projects and more active in local politics after synergetic coproduction. In terms of the effect that synergetic partnerships have on local government performance, clubs report that after the most recent transnational project, they "agree" and "strongly agree" that municipal officials were more trustworthy, more responsive to the needs of the local citizenry, and delivered on their promises to the community more consistently.

Synergetic partnerships are also more associated with increases in the share of total public spending on public goods and services in those municipalities in which 
clubs participate more frequently. On average, with each additional project completed through a synergetic partnership, the share of public spending increases by 1.2 percent in the electoral period immediately following the coproduction project. As synergetic partnerships continue in municipalities, local government is more responsive to programmatic spending on public works. While there is no association between incidence of synergetic partnerships and the party affiliation of the incumbent mayor, after repeated cases of synergy, it is more likely that the PRI is the party in power and less likely that the PAN is the municipal incumbent.

Club Nochistlan, a large club with 250 members located in Los Angeles, California, formed in 1997 and spent 11 years coordinating public goods provision in their hometown in the state of Zacatecas independently and through the federal 3x1 Program. After Club Nochistlan completed their very first project with the municipal government through the $3 \times 1$ Program, they reported that while reaction from local residents and civic associations in the hometown was very positive, local officials were more difficult to work with and the club had an unfavorable opinion of them. However, over time and after the completion of several more projects, the club noted that access to the mayor and his staff and the club's ability to influence decision-making improved considerably. In 2009 and later in 2010, club leaders described the partnership with the local government and citizens in a positive light. One club leader said she considered the transnational partnership to now be an important "local institution" for the provision of public goods regardless of the political party of the mayor in power. When I reviewed the changes in public spending on public works in Nochistlan for the years in which the club completed 3x1 projects, every additional year of project activity was associated with a $\$ 126$ peso increase (per capita) in municipal spending on public works. The survey data on synergetic partnerships supports the findings from the case study analysis: civic engagement in community activities in and beyond coproduction activities, nonelectoral forms of political participation, and government responsiveness improve with synergetic partnerships.

\section{CORPORATIST PARTNERSHIPS}

The 38 cases of corporatist partnerships were those characterized by low levels of community inclusion, but higher levels of local government engagement. In the short term, places with more corporatist partnerships are associated with more citizens participating in local elections. On average, 5 percent more citizens turn out to vote in municipalities with corporatist partnerships than in other partnership types. But while more people turn out to vote, there is no change in voter turnout in the electoral period immediately following the partnership, all other things being equal. As the analysis of government engagement reveals, citizens are more likely to turn out to vote in municipal elections compared to other partnership communities. Moreover, HTA leaders are no more likely to agree or disagree 
that citizens become more civically or politically involved in the hometown in the period after transnational partnerships.

HTA leaders' impressions of club involvement in local governance and political officials' performance is more positive. HTA leaders are more likely to "agree" and "strongly agree" that transnational partnerships give them more access to political officials and grant them decision-making authority and influence during negotiations with local officials. Leaders are also more likely to perceive local government to be more responsive, trustworthy, and perform their duties consistency well. HTA leaders' perceptions are supported by municipal budget data. In places with corporatist partnerships, the local government is more likely to spend more (4 percent) on public works in the electoral cycle after the partnership and even more than in synergetic partnerships following the most recent coproduction project. The positive spending effects disappear, however, after repeated municipal engagement in partnerships. The data suggests that increases in government spending on public goods is more likely confined to the electoral period right after the active partnership, which may suggest political opportunism. One interesting association uncovered in this analysis is that places with more corporatist partnerships are more likely located in PRD municipalities.

While corporatist partnerships are more associated with active, engaged local government that works cooperatively with migrant clubs, the public spending returns to local citizens that occur in the periods directly after partnerships are short-lived. This provides some initial evidence that corporatist partnerships may benefit local government in politically expedient ways but do little to improve government responsiveness over the longer term. The lack of social inclusion in partnerships also suggests that while migrant-state relations are cooperative, residents have little say in how public goods decisions are made and how resources are allocated. Community exclusion may lead to some short-term political activism, as the case of Atitlan reveals, but over a larger number of corporatist cases, the finding in the aggregate is that these types of partnership are more likely to reinforce the status quo level of political participation or lead to a worsening of resident involvement in community and political affairs in the hometown.

\section{SUBSTITUTIVE PARTNERSHIPS}

The 51 cases of substitutive partnership characterized by high levels of community involvement, but low levels of government support, produced mixed results for civic and political engagement and government responsiveness. Local citizens in these locales turned out to vote less in substitutive partnerships compared to other places before partnerships and there was no change in voter turnout afterward. However, as substitutive partnerships continued over time, there was a significant decline in citizen voting behaviors. In places with repeated substitution, voter turnout declined by 11 percent. This is a significant decrease in the citizen 
population participating in elections. Survey results revealed no systematic association between civic engagement after substitutive partnerships.

Additionally, local government officials in substitutive partnerships spent 3 percent less on public goods and had significantly fewer $3 \times 1$ projects compared to other types of partnerships in the short run. Municipal governments involved in these partnerships are also more likely to fall short of their full 25 percent matching contribution to migrant clubs. In substitutive partnerships, municipal government matched less than one-to-one with other cofinancing partners (state, federal, and migrant partners). Survey data suggests that HTA leaders' perceptions of government responsiveness were also more negative after coproduction activities. Leaders are more likely to "disagree" and "strongly disagree" that municipal officials did their jobs consistently well, were responsive to citizens' needs, and were more trustworthy after experiences in coordinating public goods. Leaders' perceptions of changes in citizens' involvement in civic and community affairs, however, were considerably more favorable. After the most recent projects, migrant leaders were more likely to "strongly agree" that residents become more politically active and engaged in civic affairs.

While substitutive partnerships may be inclusive of the local citizenry through processes of social learning or because migrants are embedded in the social base of the hometown, a lack of government engagement has depressive effects on public spending and negative consequences for electoral participation in the short run. Survey findings suggested that while migrant clubs were able to use their collective resources to improve public goods provision with the help of local residents, partnerships do little to improve local government performance, depress voter turnout, and have no effects on citizen engagement beyond coproduction projects. Substitutive partnerships may scale up citizen participation in voting eventually, which may, in turn, encourage local government to be more responsiveness as the case of El Cerrito illustrates in chapter 3. Longitudinal data is necessary to uncover the durability of political effects within cases and across cases over time.

\section{FRAGMENTED PARTNERSHIPS}

The 69 cases of fragmented partnership produced more negative political consequences in the period after migrant partnerships with the local government than in other coproduction types. In municipalities with fragmented coproduction, which are more likely to be characterized by low community inclusion and government engagement, partnerships had a much shorter lifespan than other types of partnerships. They were not only more likely to be clubs that reported being temporarily or permanently inactive, they were also more likely to have completed only one project through the 3x1 Program. HTA leaders in fragmented partnerships were also more likely to perceive negative consequences after their involvement in public goods provision. Leaders were more likely to "strongly disagree" 
that government officials are more responsive, reliable, and trustworthy and leaders report a higher frequency of not finishing public goods projects "often" or "very often."

Leaders' perceptions of citizen involvement in community and political activities were also more unfavorable. Survey data suggests that HTAs are more likely to "strongly disagree" that in the period right after the most recent 3x1 project, citizens were more engaged in local politics and community activities. Unlike in other partnership cases in which the length of time a club leader resides in the U.S. has no systematic effect in organizing partnerships or political consequences, HTA leaders in fragmented partnerships were more likely to reside in the U.S. for longer periods of time. In fragmented partnerships, leaders are more likely to live in the U.S. for more than 20 years than in other types of partnerships.

Taken together, results of fragmented partnerships suggest few opportunities to improve local democratic governance in the short run. Cases of fragmented coproduction were more likely to fail without local social resources and more state capacity involved in coproduction activities. The data also reveals that citizens are more likely to become politically disenchanted and are less likely to participate in civic and political affairs in the period following fragmented coproduction activities.

\section{APEX PARTNERSHIPS}

In the framework I present in chapter 1, the level of HTA capacity is held constant. When I relaxed the assumption that HTA club capacity was similar across cases, the data revealed a hybrid form of coproduction. This partnership grouping was characterized by low levels of community inclusion and government engagement but high levels of HTA capacity through which to provide local public goods without much support from other social and political actors. In these cases of coproduction, cofinancing from state and federal partners helped coproduce public works projects, but the HTA was the "apex" provider of public goods, which allowed local government to be less responsive for service provision and shirk a core responsibility of local office.

In the survey sample, 31 partnerships were apex partnerships. In apex partnerships, HTA leaders reported near unanimous disagreement that municipal government officials became more responsive, reliable, and trustworthy after coproduction projects were implemented. These clubs were also more likely to report the local government was less cooperative, and clubs had consistently more problems completing projects and receiving matching contributions in a timely manner compared to other kinds of partnerships. Club leaders in apex partnerships were also more likely to "disagree" or "strongly disagree" that participation in public goods provision gives migrants more influence and decision-making authority in local governance. Data shows that while migrant clubs were able to complete public goods projects in their hometowns with less engagement from the 
local citizenry and municipal government, apex clubs faced considerable obstacles to successfully completing coproduction projects.

There are some limitations in the survey analysis that suggest more caution when drawing conclusions. First, the number of cases of each partnership type is small, which limits confidence in the generalizability of findings. Second, the survey data is a representative sample of migrant partnerships, but only from a snapshot in time. Many of the projects that club leaders were referencing when completing the before-and-after questions on the survey occurred between 2007 and 2009, although some referenced project experiences from earlier time periods. As such, migrant clubs' reflections on how political engagement and government performance changed after coproduction projects only reflect the kind of project in that snapshot of time. As we learned in the comparative case studies, the type of partnership is likely to change over time through social learning. It is quite likely the case that some of the partnerships surveyed, especially those in the very early years of coproducing public goods with the Mexican state, changed organizational forms in later periods. To address these limitations in the survey analysis, I also assessed with multivariate statistics how repeated partnerships affect political outcomes over a longer time horizon for each type of partnership. As the results show, habitual engagement between migrants, citizens, and the local government does produce important changes over time, but a longer observation window is necessary to draw more confidence in the conclusions. ${ }^{11}$

A final limitation of the cluster analysis is that the unit of observation is the club year for the most recent before-and-after period, but the political outcomes are aggregated at the municipal level of observation. Data is unavailable at the locality level where many clubs focus their coproduction activities. To isolate the effects of the survey respondent and political effects in the municipality, I controlled for whether there were any other hometown associations in the municipal year. I also restricted the $3 \times 1$ coproduction data and municipal spending data to the specific survey respondent by matching the name of migrant club listed in the 3X1 Program data. Nonetheless, I was unable to completely isolate how the survey respondent's coproduction partnership produced changes in local civic and political engagement and government responsiveness, especially when there were other hometown clubs active in the municipality in the same time period. In the HTA survey sample, 27 percent of the sample were in municipalities with other active $3 \mathrm{X} 1$ partnerships in the same time period as the club observations. More microlevel data at the locality level would be necessary to completely rule out the possibility that different partnerships had counteracting effects on political and civic engagement and government responsiveness. Cross-checking the survey data with data from the universe of partnership cases in the $3 \times 1$ data was an important step as it showed that partnerships types can vary in the same municipality and caution must be exercised when interpreting club-level results using municipal political outcome variables. 
The survey provides a window into how partnerships are organized and how this organizational variation is associated with different political effects in a crosssection of partnership cases. Without the survey data and PCA and cluster analysis, it would have been difficult to validate whether partnerships are structured differently. Small-n case studies cannot control for the multitude of factors that likely affect partnerships. Moreover, 3x1 Program data does not have the detailed information about the nature of partnerships to assess organizational variation. The survey analysis is the first opportunity to examine organizational variation in partnership types in the specific social, economic, and political contexts of U.S. destinations and Mexican origins.

In the final stage of the empirical analysis in this chapter, I turn to panel data and statistical analysis to determine the long-term political consequences of transnational partnerships. I assess if places with transnational partnerships have a systematic effect on voter turnout and government responsiveness compared to municipalities that never participated in the 3x1 Program between 1990 and 2013. I also compare a subset of $3 \times 1$ participating municipalities. In that analysis, I analyze how municipalities that frequently engage in coproduction compare to those that participate less frequently between 2002 and 2013, the active period of the 3x1 Program. In this part of the statistical analysis, I move up a level of aggregation from club level to municipal level exclusively and examine the political effects across all transnational partnership types. Using longitudinal data from the Mexican Family Life Survey and 3x1 Program project data at the municipal level, I assess how 3X1 Program participation and the number of coproduction projects affect civic and political participation and government responsiveness across migrant hometowns.

\section{PANEL ANALYSIS USING 3X1 PROGRAM AND MUNICIPAL DATA}

To test the hypothesis that transnational partnerships affect political and civic participation and government responsiveness, I must operationalize partnerships and political outcomes. I rely on municipal participation in the 3x1 Program to account for places that formally engage in the coproduction of public goods and services between the Mexican sending state and organized migrant hometown associations. ${ }^{12}$ As I describe in chapter 2, the $3 \times 1$ Program is a federally administered social spending program that matches the collective remittances of migrant HTAs, three-to-one, at the local, state, and federal levels of government. While financing from all three levels of the Mexican government and migrant collective remittances fund project costs, all other aspects of project coordination occur at the municipal level. Project selection, planning, technical support, labor, materials, implementation, and monitoring are coordinated between municipal government officials and migrant hometown groups. I construct several indicators for 
3X1 Program participation. Additional data on the main explanatory variables and controls is presented in Data Appendix D.

Data for the analysis includes annual municipal participation and project data in the 3X1 Program from 2002, the first year of the program, to 2013, the most recent year for which complete data is available. The Secretaría de Desarrollo Social, the Ministry of Social Development (Sedesol), maintains a database of all approved $3 \times 1$ projects. The database contains annual data on project location, type, funding sources and amounts, and total number of projects for each participating municipality. The unit of analysis is the municipal-year observation. Sedesol does not report information about projects that were proposed, but not approved, by state-level project validation committees. ${ }^{13}$

The project proposal process generally proceeds as follows. First, HTAs and local government officials agree to submit a proposal for approval to a Validation Committee (COVAM), which exists in every Mexican state. The COVAM is made up of two individuals for each kind of coproduction partner including municipal, state, federal, and migrant partners. The representative body typically meets one to three times a year to approve project proposals depending on the number of proposals in each Mexican state. After the COVAM approves or rejects proposals, each cofinancing partner deposits 25 percent of the total project costs into an independent banking account or the municipal treasury. The migrant HTA and local government authorities plan, hire labor, implement, and monitor projects at variable levels of engagement.

Between 2002 and 2013, 1,234 municipalities participated at least once in the 3X1 Program, which is half (50.2 percent) of all Mexican municipalities. In 2008, for example, while 539 different municipalities participated, only 87 municipalities were participating in the program for the first time. The number of new municipalities starting the program for the first time decreases over the duration of the program. This indicates that a large number of municipalities repeatedly participate rather than indicating more diffuse policy adoption across municipalities between 2002 and 2013. ${ }^{14}$

\section{MEASURING LOCAL CIVIC AND POLITICAL}

\section{PARTICIPATION AND GOVERNMENT RESPONSIVENESS}

Researchers have different approaches for conceptualizing and measuring democratic governance. Scholarship on political democracy ranges from regime change and democratic consolidation, ${ }^{15}$ democratic quality in terms of how well democracy performs given some normative standards (for example, procedural minimums including participation and competition), ${ }^{16}$ the effects of democracy on other indicators such as economic growth and wars, and government institutional performance. ${ }^{17}$ Since I am interested in how transnational partnerships affect local democracy across standard benchmarks, I measure political effects that provide 
insight into procedural and results facets of democracy. The dependent variables of interest are political participation in elections, civic engagement in community activities and associations, and government responsiveness in terms of spending on social welfare and public works programs.

\section{POLITICAL PARTICIPATION}

Political participation refers to the extent to which citizens exercise formal voting rights as well as organize, assemble, protest, lobby, join political parties and civil society organizations, and otherwise influence the decision-making process. Democratic quality is high when citizens participate in the political process, deliberate policy issues, communicate with and demand accountability from elected representatives, and monitor the conduct of political officials. Greater formal participation makes democratic systems, in theory, more responsive to a larger share of the population. In this analysis, I restrict the focus to formal political participation and measure how many citizens of voting age cast a vote in local elections. The focus on nonmigrant citizen voting reflects the importance of electoral participation in studies of democratic participation and governance. Additionally, reliable panel indicators for more informal forms of political participation (for example, rallies, protests, and petitions) are scarce.

\section{CIVIC ENGAGEMENT}

The MxFLS data allows me to assess how 3x1 Program participation affects nonelectoral forms of political and civic engagement in addition to voting. I observe whether transnational partnerships explain changes in the frequency of community-level activities and the incidence and kind of civic associations such as social, religious, and political associations. I hypothesize that community inclusion is an important factor in organizing partnerships and that more citizen involvement increases information sharing, political interest, and awareness of government actions and behaviors while in office. Places in which the incidence of community activities increase during periods of municipal participation in the 3x1 Program provide a window into how partnerships may have positive spillovers on different forms of civic and political engagement.

Changes in levels of community activities that are positively associated with the incidence and frequency of 3X1 Program participation and the number of 3X1 projects suggest higher levels of community inclusion. I anticipate that more community inclusion may be indicative of both the role of preexisting civic associations in transnational projects and the creation of new kinds of citizen activities. Over time and with repeated social interactions between citizens, migrants, and political officials, citizens' routinized interactions will lead to more regular participation in the local civic and public affairs. In addition to analyzing the independent effects of 
coproduction on civic and political activities, I also evaluate whether civic engagement has a conditional effect on political participation. For example, if 3x1 participation is associated with increases in community civic activities, I expect that this may further increase citizens' interest and engagement in the formal electoral process. To capture the likelihood of a conditional effect, I estimate interactions between community civic engagement and 3x1 participation on voter turnout.

The MxFLS is a longitudinal, multi-thematic survey taken over three panel waves (2002, 2005-2006, 2009-2012). The survey is helpful for my purposes because in addition to an individual and household survey, there is also a community sample. The community survey includes questions about community activities across a random sample of Mexican municipalities. Using the MxFLS sample, I match municipal survey respondents with all the municipalities in the panel dataset used earlier in the chapter. Over the three panels of the MxFLS, the total number of respondent municipalities for which comprehensive data is available is 272 municipalities with some missing data. About 30 percent of MxFLS municipalities participated in the $3 \times 1$ Program during the period of study. The survey questionnaire includes a battery of questions related to community activities including whether the community organizes activities, meetings, and assemblies, and the type of community activities organized including religious, political, social, or other. The survey also collects data on whether activities are more recent and how many occur over the preceding 12 -month period. ${ }^{18}$

\section{GOVERNMENT RESPONSIVENESS}

Government responsiveness to the needs, interests, expectations, and demands of citizens $^{19}$ provides additional insight into the results dimension of transnational partnerships. Across Mexican municipalities, public goods provision is the central responsibility of local government and citizens base their evaluations of government performance on access to public works. Mexican municipalities are responsible for the provision of public goods and services and citizens know whom to reward and blame for this core responsibility. ${ }^{20}$ As per Article 115 of the Mexican Constitution, municipalities have exclusive authority over (1) provision of drinking water, drainage, and sewage systems; (2) public lighting; (3) cleaning, collection, removal, treatment and disposal of waste materials; (4) markets and supply centers; (5) cemeteries and monuments; (6) slaughterhouses; (7) streets, parks, and gardens; and (8) public security and safety. Survey data shows that citizens know the issue areas that are the exclusive domain of municipal government, can differentiate between state and local government policy responsibilities, and report that public utility provision (especially water and sewerage) are the "most important" municipal problems. ${ }^{21}$

By the same token, municipal presidents know that receiving credit for public goods provision is a key factor in determining citizens' evaluation of their 
performance while in office. Municipalities rely on a combination of federal and state transfers and local sources of revenues to finance public goods and services. Some revenue transfers sent to municipalities are based on objective criteria including population size, poverty, and relative need, but other disbursements may be politically motivated..$^{22}$ Municipal presidents maintain discretion concerning how resources are spent once they arrive from state and federal transfers. Because participation in the $3 \times 1$ Program provides amplifying funds for municipal government to finance public works, transnational partnerships are likely to affect government responsiveness.

I evaluate the extent to which $3 \times 1$ participation achieves benefits for citizens in participating municipalities by analyzing changes in government spending as an indicator of their responsiveness to coproduction. Specifically, I analyze how $3 \times 1$ participation affects municipal spending on public works (per capita) and the share of the total budget devoted to social spending. These measures are instructive because they reveal the share of funds being distributed for public works and any possible spending leakages that may occur from cofinancing from coproduction partners. For example, because I know the total budget for each 3xi project, I can examine the difference in total municipal contributions that should be spent on $3 \times 1$ projects and actual expenditures by looking at different spending categories in the municipal budget for each three-year electoral period of a single political party in power.

If political officials were more responsive to citizen demands for public works, we would expect 3x1 Program participation to increase the spending on public works as opposed to increases on personal salaries or debt services. Moreover, when municipalities match program contributions one-to-one with state, federal, and migrant partners, we should expect municipal expenditures and shares of public works to increase. No change in public expenditures would provide evidence that $3 \times 1$ participation is subsidizing public works spending that municipalities would have spent in the absence of program participation. A decrease would suggest that political officials are offloading responsibility to migrant (and state and federal government) partners and spending less than they would have spent without coproduction financing. A negative change in spending implies 3x1 Program participation is allowing municipalities to shirk their coproduction financing obligations and spend what they would have spent on public works in other budget areas. Finally, if total expenditures increase, but not a concomitant increase in public works spending, we may deduce a spending leakage in response to $3 \mathrm{x} 1$ participation. ${ }^{23}$ In other words, we may infer that municipalities are shifting expenditures to other categories in response to program participation and away from social welfare spending, which is one of the primary objectives of the federal 3x1 Program.

Civic and political participation and government responsiveness are three dimensions of governance likely affected by transnational coproduction facilitated 
by participation in the $3 \times 1$ Program. Assessing the extent to which municipal participation in the $3 \times 1$ Program affects multiple dimensions of democratic governance provides some insight into what some scholars refer to as vertical accountability. ${ }^{24}$ Vertical accountability refers to citizens' awareness and access to information about representatives' political actions and decisions while in office, their evaluation of the justifications officials provide for their actions, and their interest and capacity to impose consequences on representatives through participation in the democratic process.

\section{SYSTEMATIC EFFECTS ON LOCAL DEMOCRATIC ENGAGEMENT AND GOVERNMENT RESPONSIVENESS}

Using a difference-in-difference approach, I analyze first whether municipal participation in the $3 \times 1$ Program has systematic effects on voter turnout and government responsiveness compared to municipalities that never participated in the program from 1990 to 2013 . Results show that 3X1 municipalities are more likely to experience significant changes in voter turnout and government spending than nonparticipating municipalities. I illustrate these findings in Figure 5. Specifically, more frequent participation in the $3 \times 1$ Program significantly increases political participation compared to municipalities that never participate. In the subset of municipal cases that participate at some point between 2002 and 2013, those that participate in the $3 \times 1$ Program less frequently have less citizens turning out to vote, holding all other factors constant. For every year of participation in the $3 \times 1$ Program, the number of citizens turning out to vote increases by about 2 percent. Among the municipalities that participate in the $3 \times 1$ Program, the average frequency of annual participation is four years. For these municipalities, every four years of participation leads to an 8 percent increase in the voting-age citizenry turning out to vote in municipal elections. If a municipality participates in the 3X1 Program 10 times, for example (about 10 percent of the participating sample), the increase in voter turnout increases by about 20 percent. Since the voting-age population that turns out to vote is a relatively stable percentage in municipalities over time, the fact that participating in the $3 \times 1$ Program produces significant turnout effects is somewhat surprising and provides compelling evidence that transnational partnerships have important consequences on local electoral politics.

The results also show that municipalities that participate in the $3 \times 1$ Program and that coproduce a higher number of public goods projects increase the odds of having recent community activities (the reference group is not having any recent activity). For every additional year of municipal participation in the 3x1 Program and for each additional coproduction project that is implemented, the odds that local residents take part in community activities increase by 68 percent and 60 percent, respectively. The more that the migrant hometown participates in the 3x1 Program and has more projects, the higher the odds of having local civic engagement. 


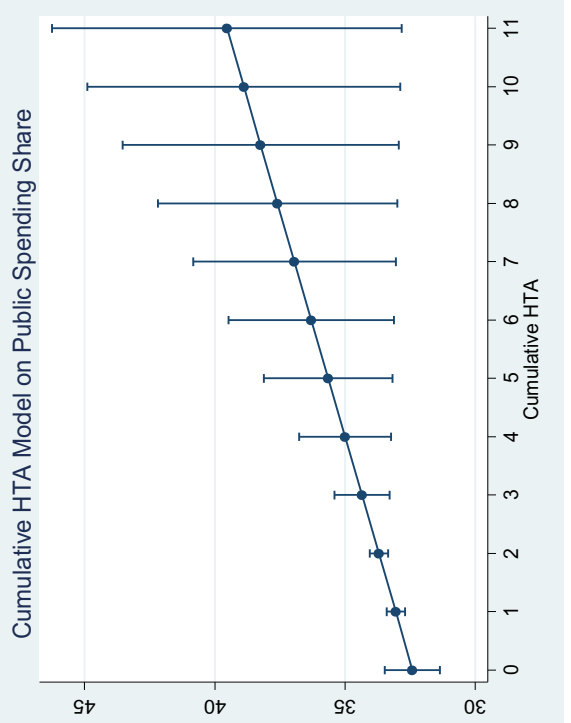

Uี

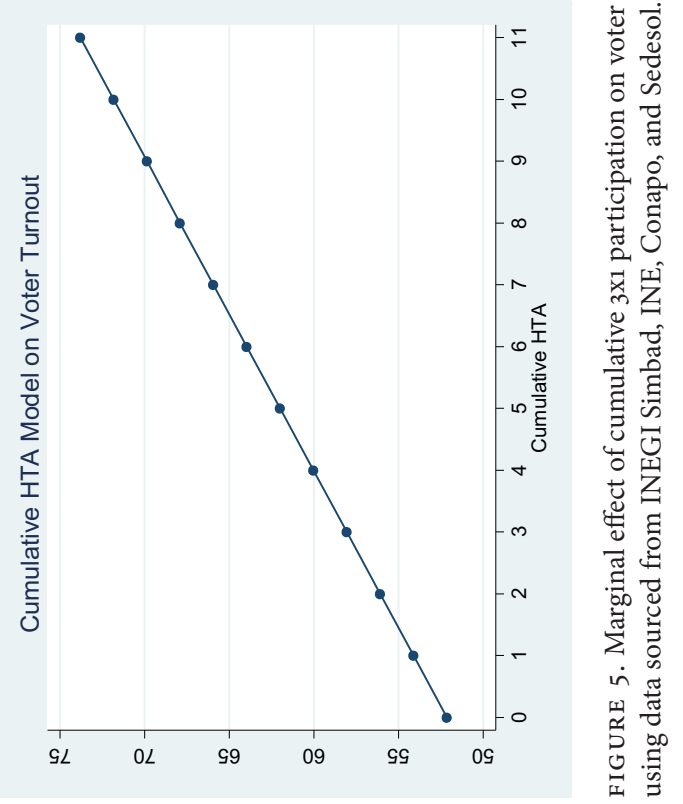


While we cannot infer that recent community activities are a direct indication of community inclusion in coproduction projects, these findings offer initial support that transnational partnerships play some positive spillover role in more citizens becoming involved in the civic affairs of their community compared to places that do not participate in the $3 \times 1$ Program. Additionally, results suggest additional support for the social learning hypothesis. As municipalities participate more in the 3x1 Program and complete more coproduction projects, the odds that community activities increase to 10 or more increase by 16.5 percent. However, in places in which the citizenry is already highly engaged in civic associations and activities that predate $3 \mathrm{X} 1$ participation, there is no evidence that additional coproduction projects further increase civic engagement. In other words, additional 3x1 projects lead to higher propensities for community engagement in places with lower initial levels of civic engagement but have no effect in places in which the citizenry was already highly active in civic associations.

The final analyses using the MxFLS examines if 3x1 participation enhances political participation (voting) conditional on civic engagement. In other words, I observe how civic engagement and 3x1 participation together affect voter turnout. While the panel data shows that more people turn out to vote in municipalities that participate in $3 \mathrm{x} 1$ projects, the MxFLS data more directly tests whether increases in citizen participation in local elections are conditional on transnational partnerships that also spur more civic engagement in local community affairs. Results reported in Data Appendix D confirm the important condition role of civic engagement on coproduction projects and their political effects.

The number of citizens that turn out to vote in elections increases by an additional 4 percent when nonmigrant citizens engage in more than 10 community activities in the preceding year. The positive effect of civic engagement and 3x1 participation holds across other indicators of 3x1 Program participation. For every additional project completed through the 3x1 Program, voter turnout increases by an additional 3 to 5 percent, depending on the level of civic engagement in the hometown. For example, in places with at least 50 community activities (a quarter of the sample), voter turnout increases by 3.4 percent for each additional 3X1 project completed. In municipalities with high levels of civic engagement and that complete at least three public works projects through the 3xi Program, we would expect voter turnout to increase about 10 percent. When community activities reach 100 (7 percent of the sample), voter turnout increases by 5.4 percent for every coproduction project completed. Figure 6 plots the marginal effects of program participation conditional on different levels of local civic engagement.

Results also show that the frequency of participation in the 3x1 Program and the number of coproduction projects have important effects on voter turnout given the type of civic engagement in migrant hometowns. When there are more social and religious kinds of community activities, each additional coproduction project increases the percent of citizens voting by about 2 percent ( 1.7 and 

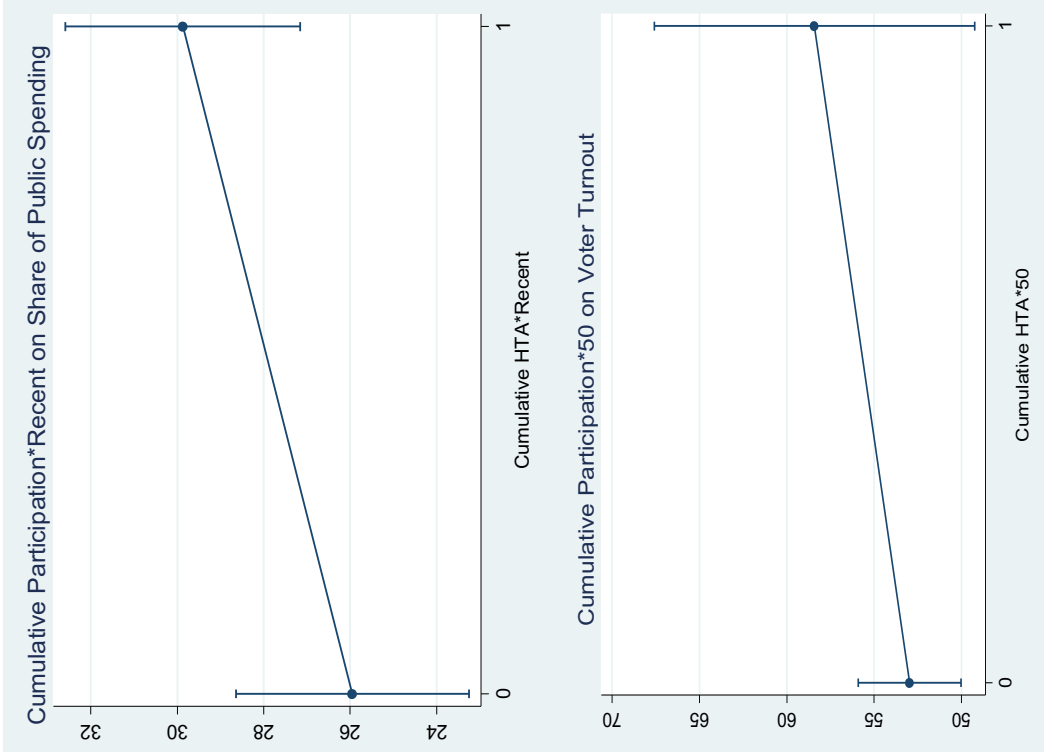

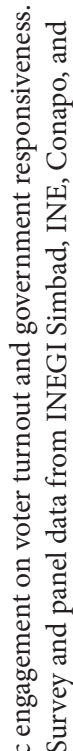

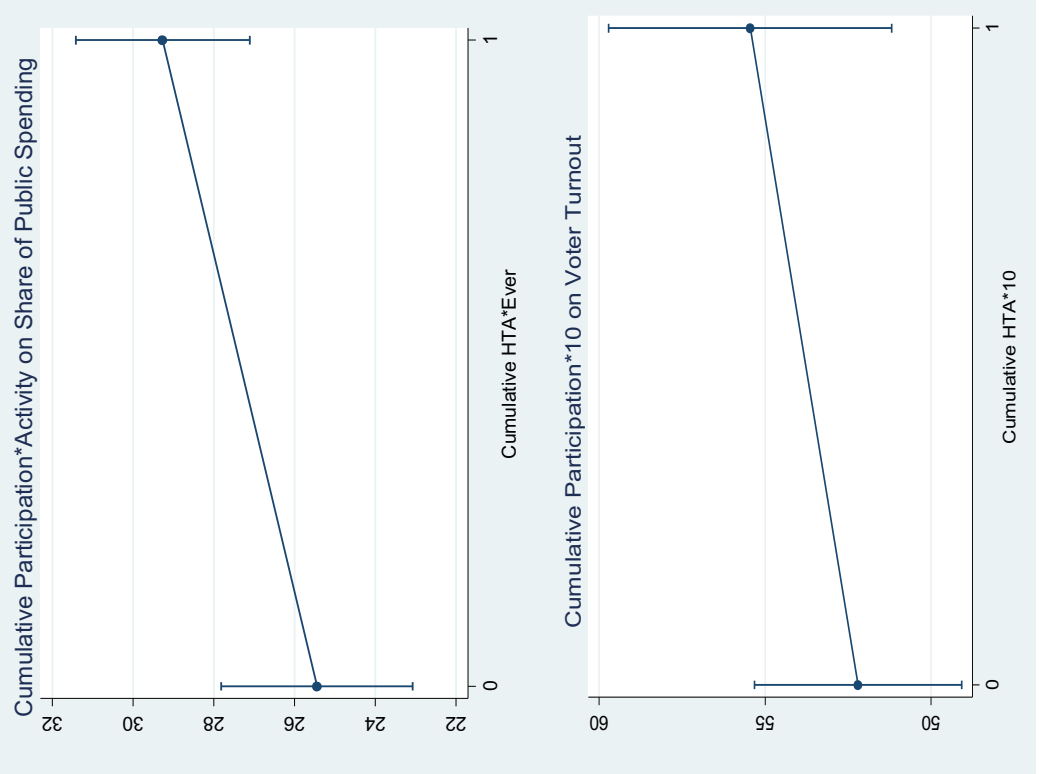

总艺

츨

혿

.ํํㄱ 즈

:

矛

记

过

丞

光

U.

节

暿譆 
1.8 percent respectively). Taken together, the interaction models confirm that the positive spillover effects on political participation in municipal elections are conditional on citizens' active participation in community civic affairs and magnify the positive effects that transnational partnerships have on nonmigrant citizens' engagement in local governance.

The central findings for government responsiveness are generally less sanguine. When a municipality participates in the $3 \times 1$ Program, there is a decrease in total spending in the municipal budget and spending on public goods and services. Places that participate in the $3 \times 1$ Program are likely to spend $\$ 37$ pesos (per capita) less on public works and $\$ 50$ pesos (per capita) less on total spending across all categories compared to municipalities that never participate in the 3x1 Program. The only gains to citizens in terms of government spending on public goods from transnational coproduction occur when municipalities are consistently engaging in the $3 \times 1$ Program over time, which is consistent with the survey findings presented earlier in the chapter. From one electoral cycle to the next (about three years), municipalities that habitually participate in the 3x1 Program spend about $\$ 21$ pesos (per capita) more on public works and increase the total share of the municipal budget by about 2 percent. When municipalities participate once or have more limited engagement in coproduction, officials are more likely to allow 3X1 spending to subsidize for municipal spending on public works.

Municipal public spending as a share of total spending also suffers when municipalities participate in the 3x1 Program less consistently. The share of public works spending declines by almost 5 percent for municipalities that participate infrequently. By comparison, in those municipalities that participate more habitually, municipal spending increases, but very minimally. For example, in the election year after $3 \mathrm{x} 1$ participation, municipalities are likely to allocate only about 0.5 percent more of their total budget expenditures to public works and are only likely to spend an additional 0.37 percent with each subsequent year of participation. To put this in perspective, consider a municipality with the mean level of expenditures. The average municipality spends about 30 percent of their total municipal budget on public goods and services. If average total expenditures per capita are $\$ 1,912$ pesos and mean public works expenditures are about $\$ 626$, participating in the $3 \times 1$ Program once corresponds to an additional $\$ 11$ pesos of spending on public works per citizen. This amounts to about $\$ 1$ USD more on public works spending per capita, which is negligible. But if a municipality participates six times, for example, public works expenditures increase by almost 2 percent. When municipalities participate once or only a handful of times, financial contributions from state, federal, and migrant partners subsidize local public works budgets at best and decrease programmatic spending at worst. Improvements in municipal social spending only occur with more frequent, consistent participation in the $3 \times 1$ Program over time and even then, on average, social spending increases only amount to a few additional dollars per citizen. 
The findings on municipal spending in response to transnational coproduction reveal that in the absence of continuous participation in the 3x1 Program, municipal government partners have an incentive to offload public works spending on organized migrant groups. Even in cases in which municipalities are habitual participants, on average, political authorities increase social welfare spending very little beyond what they commit to cofinancing public works through the $3 \times 1$ Program. In other words, beyond meeting their obligations to match coproduction project budgets in very active $3 \times 1$ municipalities, political officials are not reorganizing their municipal budgets to increase social welfare spending significantly. In those municipalities that participate in the 3x1 Program more erratically, municipal government is less responsive to the citizenry in social welfare spending than if they never participated in the program at all.

What characteristics do 3x1 participating municipalities that have the highest changes in social spending allocations share? Additional analysis shows that the places that have the highest increase in the share of public spending on public works are the poorest municipalities in the sample. Taking the results from the public spending models above into consideration, on average, when a municipality that is designated as "poor" or "very poor" by the Mexican census's marginalization index participates in the $3 \times 1$ Program 10 times, for example, the share of the total municipal budget spent on public works increases by 3 percent. For a relatively poor municipality this is a considerable increase, but this is not a majority of municipal cases.

There are two other noteworthy results. First, when poor and very poor municipalities are participating in the $3 \times 1$ Program, the data shows they are spending more of their total budgets on public goods and services than when they are not participating in the program. Results show that relatively poorer municipalities spend more on public goods (per capita) relative to richer municipalities during active periods of program participation. Second, municipalities that are the most likely to participate the most frequently in $3 \times 1$ projects $(6,8$, and 10 times) are not the poorest municipalities in Mexico. Rather, they are more likely to have a medium level of poverty according to the national marginalization index.

One policy implication from these results is that the $3 \times 1$ Program helps the worst-off Mexicans gain more access to essential public goods and services, but poorer municipalities are not participating with the same frequency as relatively wealthier locales. This may suggest that the $3 \times 1$ Program is regressive and leads to a widening of inequality in access to public goods and services in response to high levels of out-migration. However, there is an important exception to this. Since 85 percent of projects are distributed to poorer localities outside the county seat, $3 \times 1$ participation is helping poor, rural citizens gain more access to public goods in middle-income municipalities. In turn, in middle-income municipalities where poorer residents often live in outlying localities with worse public goods provision, $3 \mathrm{x} 1$ participation is likely encouraging a more egalitarian distribution of public 
resources. Finally, if more marginalized citizens are more civically and politically engaged in local politics as a result of 3x1 participation, perhaps concerns about widening inequality or the regressive nature of the program may be somewhat tempered. When marginalized citizens and citizen groups become more involved in local governance, they are using democratic channels to represent their interests and demand better government performance, which may have more long-lasting political consequences such as empowering poorer, more marginalized citizens to use their voice and demand better government performance from local officials.

While spending on public works increases in municipalities that habitually participate in the $3 \times 1$ Program, I do not observe a one-to-one increase in public spending and total expenditures. The accounting anomaly suggests municipal spending leakages in the presence of state and federal $3 \times 1$ matching funds. On average, municipalities that participate in coproduction with state, federal, and migrant club partners are not allocating all of the matching funds to public spending. Rather, matching funds allow municipal officials to change how they allocate spending across budget categories. When I consider each expenditure category of the municipal budget, results show that 3x1 not only decreases total expenditures, but that program participation leads to increases in debt and "other" municipal spending. This suggests that municipal officials are allocating some of the $3 \times 1$ monies to finance other parts of their budget such as debt obligations in lieu of spending all the money on public works and social welfare programs. ${ }^{25}$

However, the cumulative effects from continuous participation in the $3 \times 1$ Program produce opposite effects. More participation in the $3 \times 1$ program leads municipal officials to pay down less debt over time. This may occur because there is less debt to pay down or because officials are become more responsive to the citizenry and financing more public works projects the longer they engage in transnational partnerships with migrant clubs. So while social spending on public works only increases a small amount, about \$2 USD per citizen on average, municipalities that participate in the 3x1 Program frequently change how they choose to allocate public resources across different categories of the municipal budget.

The effects of $3 \times 1$ participation and civic engagement on government responsiveness using data from the MxFLS are consistent with findings from the panel analysis, but the magnitude of the effect is stronger. More recent community engagement is associated with a 4 percent increase in the share of social spending on public works in the municipal budget. The strongest conditional effects of $3 \mathrm{x} 1$ participation and civic engagement are in changes to municipal spending on public works as a share of the total budget. Municipal governments spend more of their total budgets on public works as a function of participation in the $3 \times 1$ Program when community activities reach 50 cumulative projects. But at low levels of community involvement (10 activities), municipal governments allow 3x1 participation to subsidize social spending. These findings suggest that in places in which local civic engagement is high, $3 \times 1$ participation increases municipal 
spending even more on public goods and services including electricity, potable water, streets and roads, and other public infrastructures. At lower levels of civic engagement, however, 3x1 Program participation lets local public officials off the hook for public spending and decreases their responsiveness to the public.

Consistent results from two different data sources provide compelling evidence of the returns to social spending and civic and political participation in places that have transnational partnerships with an engaged, active citizenry. As more citizens become actively engaged in coproduction activities and in community and political affairs more generally, local government becomes more responsive to citizens' demands for public goods and social welfare spending. As civic engagement increases, the positive effects of $3 \times 1$ participation are amplified. Participation in the 3x1 Program spurs more civic engagement and, in turn, more civic engagement increases voter turnout in local political participation, all other things being equal. This account indicates evidence of a "virtuous circle" stemming from cumulative, repeated engagement in coproduction activities where state and nonstate actors learn new ways to deliberate and cooperate in the fuzzy space between the public and private spheres of local governance. ${ }^{26}$

The more that migrant, resident, and government actors work together to provide public goods and are more generally active in local civic and political affairs, the more likely coproduction activities strengthen municipal government responsiveness. Even though elected officials are often only increasing public goods spending by 2 and 3 percent, they are doing so in response to citizens demanding programmatic spending increases, especially in localities that exist outside the municipal center. Survey results show that local citizens consistently identify public goods provision as the most pressing municipal concern when asked about government performance. When citizens are actively involved in deliberations about the distribution of public funds, more spending on public goods occurs in lieu of increases in other budget categories including debt spending, payroll salaries, or targeted transfers to citizens in return for political support. Additionally, citizen deliberation in public decisions about how much municipal budgets spend on what kinds of public goods and services increases regular interactions between citizens and the representatives they elect to serve. As more citizens become regularly involved in spending and allocation decisions concerning public goods, more equitable decisions are made that benefit a broader swath of the local citizenry in and beyond heavily populated town centers.

\section{TESTING ALTERNATIVE HYPOTHESES}

I argue that how much money migrants send collectively is not as important for understanding the effects of transnational coproduction on local governance as variation in the organization forms of partnerships. But this is an empirical question. Maybe it is the case that when migrant clubs propose projects with higher 
budgets that commit them to invest more money, local officials change their behavior. Perhaps when migrant clubs propose more coproduction projects, government responsiveness and local citizens' civic and political engagement improve. I examine these alternative hypotheses and ask: Are places that have more 3X1 projects or higher 3x1 expenditures more likely to observe changes in democratic functioning regardless of how transnational partnerships are organized?

Using the panel dataset, I examine how the total number of annual projects and $3 \times 1$ spending across municipalities affect civic and political participation and government responsiveness. Results show total 3x1 spending has a statistical effect on voter turnout, but the effects are overall negative and not substantively significant (see Data Appendix D). On average, total 3x1 Program expenditures lead to a decline in the number of voters turning out to cast a ballot in municipal elections by 0.3 percent. Those municipalities where $3 \times 1$ expenditures surpass $\$ 50,000$ will see a decline in voter turnout by as much as 2.5 percent, but there are few municipalities with annual expenditures that high. There are no significant effects for the number of total projects on political and civic participation or government spending.

These findings suggest that how much money migrant groups and their coproduction partners spend on public works is not the key for understanding how transnational collective action affects local democratic governance. Rather, the frequency of program participation and the nature of the involvement of local civil society and municipal government shed more light on the political consequences at the local level. Interestingly, in places with higher than average spending through the 3x1 Program we see less formal engagement in municipal politics. I argue that how citizens are included and local government is engaged in partnerships and the frequency of interaction between migrant, political officials, and residents explains a great deal more of the variation in local democratic governance over time and place than how much money migrants send home in collective remittances for public goods provision.

\section{SUMMARY}

Migrant transnational partnerships are politically consequential for migrant places of origin. As more people leave their communities of origin, form migrant clubs, and partner with the sending state, more citizens take part in the formal electoral process, especially with more frequent, engaged coproduction activities across borders and in places with more robust civil society. As the survey analysis reveals, when citizens take part in partnerships with an engaged local government repeatedly, more citizens take part in formal and informal modes of political participation. Moreover, when transnational coproduction creates civic engagement and builds on social assets available in the hometown, local democratic engagement improves even more. 
The effects of partnerships on government responsiveness are more mixed. Survey results show that substitutive partnerships subsidize public works spending for local governments but increase the share of government social spending in corporatist and synergetic partnerships over time. The more positive effects on democratic governance emanating from transnational partnerships are realized with repeated participation in the 3x1 Program, lending more support to the hypothesis that social and political learning occurs through the repeated process of transnational engagement in local public goods provision.

Findings from this chapter suggest that municipal 3x1 participation, in part, makes citizens more aware of and better informed about government officials' decisions in office. When territorial and extraterritorial citizens alike engage in coproduction activities, the relational context serves as a "school of democracy." And as the active civic and political engagement of the local citizenry improves, it has positive spillovers on government performance. The results suggest that transnational partnerships that are more inclusive of the local citizenry and spur civic engagement are also likely to induce a measure of vertical accountabilitymechanisms that enable citizens as electors to evaluate government performance through formal channels like voting. Migrant collective action in hometown development has an additive effect on both civic engagement and political turnout. But the results also suggest that synergy is not the only kind of partnership important for affecting democratic engagement. Repeated, cumulative participation in coproduction spurs civic and political engagement and government responsiveness. Transnational partnerships structurally vary across cases and over time, producing short-term consequences for local democracy. But the most profound changes from partnerships occur over a longer time horizon in which organizational variation of partnerships is likely to change through repeated, cumulative participation in the coproduction of public goods across national borders. 